\title{
DETECTION OF PESTICIDE RESIDUES IN MILK AND SOME DAIRY PRODUCTS
}

Ayoub, M. M..$^{1^{*}}$; M. E. Desoki ${ }^{2}$; A. S. Hassanin ${ }^{1}$; W. M. Thabet ${ }^{1}$; M. H. Mansour ${ }^{3}$; Nagwa M. Loutfy ${ }^{4}$; Amal Raslan ${ }^{5}$

1- Center Laboratory for Residue Analysis of Pesticides and Heavy Metals in Food, Agric. Res. Center, Ministry of Agriculture, Egypt

2- Agric. Res. Center, Ministry of Agriculture, Egypt

3- Food Hygiene Dept., Fac. of Veterinary Medicine, Zagazig Univ., Egypt

4- Plant Protections Dept., Suez Canal University, Ismailia, Egypt

5- Food Control Dept., Fac. of Veterinary Medicine, Zagazig Univ., Egypt

\section{ABSTRACT}

The study were conducted to monitor and determine the presence organochlorine pesticide residues in raw buffalo's milk and some milk products. The studied samples were collected from different regions, Sharkia Governorate, Egypt. The effect of heat treatment on pesticide residue in raw buffalo's milk and butter was also studied. The results showed that the only detected organochlorine pesticide residues in all examined milk samples was p,p'-DDE. Resides of DDE detected in yoghurt were $2.7298 \pm 0.1126 \mathrm{ppb}$, with a mean value of $1.9161 \pm 0.0992 \mathrm{ppb}$., while no residues were detected in cottage cheese samples. The organochlorine pesticide residues detected in butter samples were lindane, heptachlor epoxide and p,p'-DDE with mean values of $7.428 \pm 1.667,3.384 \pm 1.583$ and $67.063 \pm 4.933 \mathrm{ppb}$ on fat basis, respectively. Effect of common heat treatment on p,p'-DDE residues in raw buffalo's milk treated by pasteurization, boiling and sterilization, were $2.509,0.932$ and 0.2599 ppb on milk basis, respectively with degradation percent of $22.13,71.16$ and $92.8 \%$, respectively. Resides detected in butter samples after heating processing to produce ghee were lindane, heptachlor epoxide and p,p'-DDE with a mean concentration $2.948,1.935$ and $15.609 \mathrm{ppb}$ on fat basis respectively with degradation percent of $79.1,87.50$ and $76.76 \%$, respectively. We can conclude from the study that, the sterilization of raw milk is the most effective method for reduction of pesticide residues. The butter processing by heat treatment produced ghee (Samna) with marked decrease in organochlorine residue content.

Keywords: Detection, Pesticide, Residue, Milk, Dairy Product

\section{INTRODUCTION}

Milk is an essential nutritional food for infant's as well as all other age stages.

Contaminations of milk and dairy products with residues of pesticides poses serious risks to consumers.. (Abu-Zahw et al., 1993).

Pesticides were identified as one of the major environmental pollutants. The environmental pollution with organochlorines has decreased due to restriction and /or banning of these compounds. However, several recent reports (Costabeber et al., 2001; Pandit et al., 2002; Pardio et al., 2003; Waliszewski et al., 2003 ; Zhong et al., 2003 and Battu et al., 2004) indicated that pollution with organochlorines pesticides is still reported in many parts of the world.

* TO WHOM CORRESPONDENCE SHOULD BE DIRECTEE M.ELMEKAWY@GMAIL.COM 
Animals are exposed to pesticide pollution from environment and ingestion of contaminated feed and water. The milk and its products are one of the important media for accumulation of organochlorine pesticides (Mukherjee and Gobal, 1993). Because of their environmental stability and lipophilic property, organochlorine pesticides and their metabolites tend to accumulate in the milk fat (Aman and Bluthgen, 1997). The rate of excretion into milk depends on the stage of lactation, the quantity of milk fat, the amount consumed daily and the duration of exposure (Vreman et al., 1977).

The contamination of milk and its products with organochlorine pesticide and their metabolites have been recorded in different countries. In Egypt, although the use of organochlorine pesticide has been banned in 1980 (El-Marsafy et al., 1999), high amount of these chemicals were found in milk and milk products collected from different localities (Dogheim et al.,1988; Dogheim et al., 1990; Abu-Zahw et al., 1993; Abd El-Kader et al., 1994; Zidan et al.,1994; Ragab et al., 1996; Aman and Bluthgen, 1997; NeamatAllah, 1998; Dabiza et al., 1999 and Ayoub, 2000)

Organochlorine pesticides are a source of several chronic diseases, including cancer, liver and kidney disfunction, growth depression and neuritis (Oestreicher, et al., 1971, IARC 1974 and Sandhu 1992). Therefore, contamination of milk and milk products with pesticides need further emphasis over our country to probe and control such pollution.

The specific objectives of this study are:

1- Determination of organochlorine pesticide residues in raw buffalo's milk and milk products (yoghurt, kareish cheese and butter) collected from different districts at Sharkia Governorate.

2- Study the effect of heat treatment on the level of organochlorine pesticide residues in raw milk.

3- Study the effect of butter processing by heat treatment (ghee manufacture) on organochlorine pesticide residues.

\section{MATERIALS AND METHODS}

\section{A- Collection of samples}

A total of 138 random samples (72 samples of raw buffalo's milk, 24 yoghurt, 24 Kareish cheese and 18 butter) were collected from different districts, January 2002 to April 2003.

Raw buffalo's milk samples $(500 \mathrm{ml}$ each) were collected from street peddlers and dairy shops in clean glass containers. While, yoghurt samples were collected from dairy shops and supermarkets in its original containers. The cottage cheese samples (250 gm each) and butter samples (one kg each) were collected from public markets in villages and kept in clean and dry sampling jars.

Each collected samples was labeled to identify the source, site and date of sampling, and transferred to the laboratory without delay. Delayed samples were stored in ice bag. 
B. Preparation of Samples

1- Milk and yoghurt: Each sample of raw milk or yoghurt was thoroughly mixed and a sub sample of $10 \mathrm{ml}$ was measured in small glass containers with screw Teflon capped stoppers and kept deeply frozen at $20{ }^{\circ} \mathrm{C}$ for pesticide residues analysis.

2- Cottage cheese: Twenty five gm of each cheese sample was thoroughly meshed with $50 \mathrm{ml}$ of distilled water in a clean dry blender, then $10 \mathrm{ml}$ from each prepared sample was measured into small glass containers with screw Teflon stoppers and kept deeply frozen at $-20{ }^{\circ} \mathrm{C}$ for analysis.

3- Butter: Each sample was divided into 2 portions and each portion was kept in clean dry glass container. The first portion $(250 \mathrm{gm})$ was warmed to about $50{ }^{\circ} \mathrm{C}$ until fat separate and decanted through dry filter paper No. 10 , and then $3 \mathrm{gm}$ were taken for pesticide analysis. The second portion (750 gm) was kept in deep freezer at $-20{ }^{\circ} \mathrm{C}$ for processing by heat treatment (ghee manufacture).

I- Determination of organochlorine pesticide residues in milk and other milk products

A-Extraction procedure

1- Milk, Yoghurt and Kareish cheese

The extraction of milk, yoghurt and kareish cheese samples was carried out according to Suzuki et al. (1979) and Riva and Anadon (1991)

\section{2- Butter}

The extraction of butter samples was conducted according to Corneliussen et al. (1984)

\section{B-Clean up:}

All extracts of milk, yoghurt, cheese and butter were subjected to clean up procedure according to Suzuki et al., (1979)

\section{C-Quantitative determination of organochlorine pesticides \\ 1- Preparation of stock standards}

Pesticides stock standard were prepared in $\mu \mathrm{g} / \mathrm{ml}$ concentration by dissolving $0.1 \mathrm{gram}$ of the standard in $100 \mathrm{ml}$ pesticide quality hexane using volumetric flask. The stock solution was transferred to ground glass Stoppard reagent bottles and stored in refrigerator.

\section{2- Preparation of chromatographic working standards}

Standard solutions were prepared from the stock solution using microsyrings. A typical concentration $(1 \mathrm{ng} / 1 \mu \mathrm{l})$ was prepared by diluting 0.1 $\mathrm{ml}$ of stock solution to $100 \mathrm{ml}$ using hexane. The standard solution were transferred to ground glass Stoppard bottle and stored in refrigerator.

\section{3- Preparation of extracted samples}

The extracted sample was diluted with $0.5 \mathrm{ml}$ of nanograde hexane. Five $\mu \mathrm{l}$ of diluted extract were injected into Electron capture gas liquid chromatography using standard microsyring.

4- Analysis on Gas liquid chromatography

Gas liquid chromatography Hewlette packared 5890 Series II equipped with double Electron Capture Detectors (ECD's $\mathrm{Ni}^{63}$ ) and double columns system was used for identification, quantification and confirmation of organochlorine pesticide residues under the conditions illustrated in Table (1). Confirmation of the results was carried out by injection two different columns 
of gas liquid chromatography. Retention times for organochlorine pesticide were calculated relative to aldrin as show in Table (2) to avoid daily deviation in retention times.

Table (1): Conditions of gas chromatographic determination

\begin{tabular}{|c|c|c|c|c|c|c|c|c|}
\hline \multicolumn{3}{|c|}{ Columns } & \multicolumn{4}{|c|}{ Temperature Program } & \multirow{2}{*}{\multicolumn{2}{|c|}{ Conditions }} \\
\hline & Column 1 & Column 2 & Level & $\begin{array}{l}\text { Rate } \\
\text { oC/min. }\end{array}$ & $\begin{array}{c}\text { Temp } \\
\text { (oC) }\end{array}$ & $\begin{array}{l}\text { Time } \\
\text { (min) }\end{array}$ & & \\
\hline \multirow{2}{*}{ Name } & PAS- 5\%phenyl & PAS-1701-14 & 1 & --- & 90 & 2 & Inject.Temp. & $225^{\circ} \mathrm{C}$ \\
\hline & Methyl Siloxane & $\begin{array}{l}\text { Cyanopropyl } \\
\text { phenyl } \\
\text { Methyl }\end{array}$ & 2 & 20 & 150 & 0 & Detec.Temp & $300^{\circ} \mathrm{C}$ \\
\hline $\begin{array}{l}\text { Film } \\
\text { thickness }\end{array}$ & 0.52 um & 0.25 um & 3 & 6 & 270 & 25 & Carrier gas & $\mathrm{N}(2 \mathrm{ml} / \mathrm{m}$ \\
\hline Length & $25 \mathrm{~m}$ & $25 \mathrm{~m}$ & & & & & & \\
\hline Column I.D. & $0.32 \mathrm{~mm}$ & $0.32 \mathrm{~mm}$ & & & & & & \\
\hline Phase ratio & 150 & 320 & & & & & & \\
\hline
\end{tabular}

Table (2): Retention times of organochlorine pesticide relative to aldrin

\begin{tabular}{|c|c|c|}
\hline Organochlorine pesticides & $\begin{array}{c}\text { Column(1) } \\
\text { (PAS-5) }\end{array}$ & $\begin{array}{c}\text { Column(2) } \\
\text { (PAS-1701) }\end{array}$ \\
\hline$\alpha-\mathrm{HCH}$ & 0.73 & 0.81 \\
\hline HCB & 0.74 & 0.73 \\
\hline$\beta-\mathrm{HCH}$ & 0.78 & 1.06 \\
\hline $\mathrm{y}$-HCH (lindane) & 0.79 & 0.96 \\
\hline Heptachlor & 0.93 & 0.94 \\
\hline Aldrin & 1 & 1 \\
\hline Heptachlor epoxide & 1.08 & 1.19 \\
\hline$p, p^{\prime}-D D E$ & 1.20 & 1.27 \\
\hline Dieldrin & 1.21 & 1.29 \\
\hline Endrin & 1.25 & 1.34 \\
\hline p,p-DDD & 1.29 & 1.37 \\
\hline o,p'-DDT & 1.30 & 1.45 \\
\hline p,p'-DDT & 1.35 & 1.48 \\
\hline
\end{tabular}

\section{5-Rate of recovery:}

The reliability of analytical method was examined by fortifying the tested samples with known quantities of tested pesticides followed by the same procedure of extraction, clean up and analysis. The percentage rates of recoveries of organochlorine pesticides were recorded in Table (3). 
Table (3): Recovery percent of organochlorine pesticides as a result of fortification of milk, cheese, butter and yogurt

\begin{tabular}{|l|c|c|c|c|}
\hline \multicolumn{1}{|c|}{ Organochlorine pesticides } & Milk & Cheese & Butter & Yoghurt \\
\hline Alpha-HCH & 89 & 79 & 78 & 80 \\
\hline Gamma-HCH & 84 & 100 & 80 & 96 \\
\hline Beta-HCH & 90 & 78 & 78 & 79 \\
\hline DDT-o,p & 96 & 90 & 93 & 87 \\
\hline DDT-p,p & 82 & 76 & 76 & 83 \\
\hline DDE-p,p & 101 & 96 & 95 & 90 \\
\hline DDD-p,p & 90 & 83 & 90 & 96 \\
\hline Heptachlor & 96 & 85 & 87 & 75 \\
\hline Heptachlor epoxide & 99 & 94 & 79 & 91 \\
\hline Dieldrin & 80 & 90 & 96 & 85 \\
\hline Endrin & 91 & 87 & 90 & 83 \\
\hline
\end{tabular}

The results for the individual pesticide were calculated from the area displayed by the integrator attached to the instrument and corrected according to the rates of recovery obtained in Table (3).

II - Study the effect of common heat treatment on the level of pesticide residues in raw buffalo's milk:

\section{A-Collection of samples:}

Three raw buffalo's milk samples (4 liter each) were collected from dairy shops in Zagazig city, Sharkia Governorate. The samples were kept frozen till the experimental procedure was carried out.

\section{B- Experimental procedure:}

The raw buffalo's milk sample (4 liter) was elevated at room temperature and thoroughly mixed to ensure equally distribution of fat globules. Ten $\mathrm{ml}$ were taken and prepared by extraction and cleaned up for pesticide residue analysis as mentioned before in experiment (1). The raw milk sample was divided into 3 equal portions (one liter each) and subjected to heat treatment as the following:

1- Laboratory pasteurization: the $1^{\text {st }}$ portion was heated at $62.8^{\circ} \mathrm{C}$ for 30 minutes in thermostatically water bath and then immediately cooled.

2- Boiling: the $2^{\text {nd }}$ portion was heated with stirring to boiling point for 5 minutes and then cooled.

3- Sterilization: the $3^{\text {rd }}$ portion was heated at $121^{\circ} \mathrm{C}$ for 15 minutes in an autoclave and then cooled.

After heat treatment (pasteurization, boiling and sterilization), $10 \mathrm{ml}$ were taken from each portion and prepared by extraction and cleaned up for pesticide residue analysis as previously mentioned in experiment (1).

III - Study the effect of butter processing by heat treatment (ghee manufacture) on pesticide residues.

\section{1-Collection of samples:}

From previously collected butter samples, 3 samples which had the highest concentration of pesticide residues were selected for this experiment. 2-Experimental procedure:

The butter samples (750 gm each) were elevated to room temperature. Each sample was melted gradually by heating in stain steel pen. Temperature was raised gradually till having characteristic turbid foams on 
the surface. Finally, the temperature was raised again till formation clear supernatant layer, bring yellow color of solid not fat at the bottom (morta) and appearance the characteristic odor of ghee. The clear supernatant layer was drained carefully into special container and kept in refrigerator till analysis was carried out.

Three gm of each ghee samples were extracted and prepared using the same procedure employed for fresh butter as mentioned in experiment

\section{RESULTS AND DISCUSSION}

\section{1- Organochlorine pesticide residues in raw buffalo's milk}

Results, Table (4) showed that p,p'-DDE was the only detected organochlorine pesticide residues in all examined raw buffalo's milk, with a concentration varies between 0.899 to 4.714 , with a mean value of $2.7298 \pm 0.1126 \mathrm{ppb}$ on milk basis. These results are rather similar with those recorded by Acqua et al. (1982) and Losada et al. (1996). Higher residue levels of p,p'-DDE were reported by Dogheim et al. (1988).; Ali et al. (1993).; Abou-Zeid (1994).; Ejobi et al. (1996).; Abou-Arab (1997).; El Afi et al. (1997).; Barkatina et al. (1999).; El-Marsafy et al. (1999) and Pardio et al. (2003).

Table (4): Organochlorine pesticide residues (ppb on milk basis) in all examined raw buffalo's milk samples collected from various districts at Sharkia Governorate.

\begin{tabular}{|c|c|c|c|c|}
\hline $\begin{array}{c}\text { Organochlorine } \\
\text { pesticide residues }\end{array}$ & $\begin{array}{c}\text { No. of } \\
\text { examined } \\
\text { samples }\end{array}$ & Maximum & Minimum & Mean \pm S.E. \\
\hline p,p-'DDE & 72 & 4.714 & 0.899 & $2.729 \pm 0.1126$ \\
\hline
\end{tabular}

it was also noticed that $p, p^{\prime}-D D E$ was the only residue detected in all examined raw buffalo's milk samples, with no other organochlorine residues detected in the same samples. Similar results were obtained by also reported on bufflo's milk El-Marsafy et al. (1999).

Ahmed (1991) reported that for more than thirty years, DDT was extensively used for pest control and public health. More than 13000 metric tones of the active ingredient of DDT have been sprayed all over Egypt, causing significant contamination of many environmental segments

DDT was officially banned in Egypt in the early 1980s, however Kelthane, one of DDT derivatives that contains residues of DDT and DDE was still in use for some years, causing some notable contamination (Camoni et al.,1983).

Animals are exposed to pesticide pollution from the environment and ingestion of contaminated feed and water (Abu-Zahw et al., 1993). DDT in feed and water of the cow is converted into DDD by the action of microflora in the rumen. In animal tissues DDD is further metabolized to DDE which is more lipid soluble than DDT or DDD (Roos and Tuinstra 1991).

Levels of organochlorine compounds detected in buffalo's milk are shown in table $(5$ 
Table (5): Organochlorine pesticide residues (ppb on milk basis) in examined raw buffalo's milk samples in relation to different districts at Sharkia Governorate

\begin{tabular}{|l|c|c|c|c|}
\hline \multirow{2}{*}{\multicolumn{1}{|c|}{ Districts }} & \multirow{2}{*}{$\begin{array}{c}\text { No. of } \\
\text { examined } \\
\text { samples }\end{array}$} & Maximum & Minimum & Mean \pm S.E. \\
\cline { 3 - 5 } & 24 & 4.714 & 0.899 & $1.215 \pm 0.101$ \\
\hline Zagazig & 24 & 4.021 & 0.990 & $2.501 \pm 0.367$ \\
\hline Abo-Hammad & 24 & 4.557 & 0.998 & $1.634 \pm 0.203$ \\
\hline Fakous & &
\end{tabular}

The results indicates that all examined raw buffalo's milk samples having p,p'-DDE residues, but the values in all examined samples were within the permissible limit ( 20 p.p.m. of total DDT and its derivatives) recommended by Codex Alimentarius Commission (2004). These results agreed with those obtained by Ahmed (1991), Abou-Zeid (1994).; Abou-Arab (1997) .; Mallatou et al. (1997).; Barkatina et al. (1999).; El-Marsafy et al. (1999) .; and Pandit et al. (2002) who reported that the p,p'-DDE residues were detected in raw milk samples with a concentration within the permissible limit. On the other hand, Puchwein et al. (1990) .; Awasthi and Ahuja (1995).; Wong and Lee (1997) and Dabiza et al. (1999) reported p,p-DDE residues above the permissible limit.

Although the p,p'-DDE in examined raw buffalo's milk did not exceed the permissible limit, the presence of such compound in buffalo's milk may act as a source of hazard for human health.

2- Organochlorine pesticide residues in yoghurt

Resides of organochlorine detected in yoghurt samples are shown in Table (6) .Results showed that p,p'-DDE was the only detected compound, with concentrations ranging between 0.887 to 2.860 with a mean value of $1.9161 \pm 0.0992 \mathrm{ppb}$. These concentrations are lower than those obtained by Kandil et al. (1987).; Ali et al. (1993).; Abou-Zeid (1994) and El-Marsafy et al. (1999). On the other hand, El-Hoshy (1997) reported that the processing of milk into yoghurt has a significant role in reducing of the insecticide residues in milk.

Table (7) would alsos show the various concentrations of organochlorines detected in various counties included in the study.

Table (6): Organochlorine pesticide residues in all examined yoghurt and Kareish Cheese samples (ppb) collected from different districts at Sharkia Governorate

\begin{tabular}{|l|c|c|c|c|}
\hline \multirow{2}{*}{ Milk products } & \multirow{2}{*}{$\begin{array}{c}\text { No. of } \\
\text { examined } \\
\text { samples }\end{array}$} & Maximum & Minimum & Mean \pm S.E. \\
\cline { 3 - 5 } & 24 & 2.860 & 0.887 & $1.9161 \pm 0.0992$ \\
\hline Yoghurt & 24 & N.D. & N.D. & N.D. \\
\hline Kareish cheese & &
\end{tabular}


Table (7): Organochlorine pesticide residues in examined yoghurt samples (ppb) in relation to various districts at Sharkia Governorate

\begin{tabular}{|l|c|c|c|c|}
\hline \multirow{2}{*}{ Districts } & \multirow{2}{*}{$\begin{array}{c}\text { No. of } \\
\text { examined } \\
\text { samples }\end{array}$} & Max. & Min. & Mean \\
\cline { 3 - 5 } & 8 & 2.201 & 0.887 & $1.594 \pm 0.112$ \\
\hline Zagazig & 8 & 2.860 & 1.897 & $2.373 \pm 0.102$ \\
Abo- Hammad & 8 & 2.313 & 1.373 & $1.987 \pm 0.118$ \\
\hline Fakous & 8 &
\end{tabular}

Results revealed that all examined yoghurt samples were contaminated with p,p'-DDE, but the value were within the permissible limit (20 p.p.m. of total DDT and its derivatives) established by Codex Alimentarious Commission (2004). El-Marsafy et al. (1999) recorded that the only residues that can detected in yoghurt samples collected from Agricultural Research station of Kafer El Sheik, was p,p'-DDE with a concentration not exceeded the codex Alimentarious residue limits.

\section{3-Organochlorine pesticide residues in kareish cheese}

No residues of organochlorine were detected in cottage cheeseTable (6). This may be attributed to either absence or low fat percent in cottage cheese. Roose and Tuinstra (1991), recorded that most organochlorine insecticides are readily excreted in milk fat, because of their lipophilic nature and relatively stability.

On the other hand, El-Marsafy et al. (1999) reported that the average of p,p'-DDE residue amounts detected in cottage cheese were $0.0109 \mathrm{mg} / \mathrm{kg}$ on fat content basis which less than that detected in raw, ripened and pasteurized milk samples and storage process caused a significant decreasing after 15 days of storage. Moreover Pietrino (1991) recorded that the microflora used in cheese making may degrade pesticide residues during cheese ripening.

\section{4- Organochlorine pesticide residues in butter}

Table (8) shows that the organochlorine pesticide residues detected in butter samples collected from various districts at Sharkia Governorate were lindane, heptachlor epoxide and p,p'-DDE.

Regarding lindane (gamma isomer of $\mathrm{HCH}$ ) residues in butter samples, it clear that the residues were detected in butter samples collected from Abo-Hammad; Hehiaa; Abo-Kaber; Al-Husenia and El-Korine with a concentration of 10.91-10.10; 12.09-12.0; 13.02-12.88; 18.12-17.99 and 13.61-12.96 ppb on fat basis, respectively. On the other hand, lindane could not be detected in the examined butter samples collected from Zagazig, Fakous, Kafr-Sakr and Menia El-Kamh. 
Table (8): Organochlorine pesticide residues(ppb on fat basis) in examined Butter samples collected from various districts at Sharkia Governorate

\begin{tabular}{|l|c|c|c|}
\hline \multicolumn{1}{|c|}{${ }^{\star}$ Districts } & Lindane & Heptachlor epoxide & p,p'-DDE \\
\hline \multirow{2}{*}{ Zagazig } & N.D. & N.D. & 51.415 \\
& N.D. & N.D. & 48.971 \\
\hline \multirow{2}{*}{ Abo-Hammad } & 10.91 & 17.05 & 65.08 \\
& 10.10 & 16.90 & 64.899 \\
\hline \multirow{2}{*}{ Fakous } & N.D. & N.D. & 59.242 \\
& N.D. & N.D. & 60.605 \\
\hline \multirow{2}{*}{ Hehiaa } & 12.09 & N.D. & 75.64 \\
& 12.00 & N.D. & 62.91 \\
\hline \multirow{2}{*}{ Abo-Kaber } & 13.02 & N.D. & 69.54 \\
& 12.875 & N.D. & 62.91 \\
\hline \multirow{2}{*}{ Kafr-Sakr } & N.D. & N.D. & 102.5 \\
& N.D. & 13.60 & 101.57 \\
\hline \multirow{2}{*}{ Al-Husenia } & 18.12 & 13.37 & 38.89 \\
& 17.99 & N.D. & 30.00 \\
\hline \multirow{2}{*}{ Al-Korin } & 13.61 & N.D. & 97.19 \\
\hline \multirow{2}{*}{ Menia El-Kamh } & 12.96 & N.D. & 93.38 \\
\hline Maximum & N.D. & N.D. & 65.16 \\
Minimum & N.D. & 17.05 & 57.227 \\
Mean \pm Error & 18.12 & 13.37 & 102.50 \\
\hline N.D. Not detected & 10.101 & $3.384 \pm 1.583$ & 30.00 \\
\hline
\end{tabular}

N.D. : Not detected

*2 samples were collected from each district

In all examined butter samples, the maximum concentration of lindane was 18.12 , while the minimum was 10.101 with a mean value of $7.428 \pm 1.667 \mathrm{ppb}$ on fat basis. These results were nearly similar to those recorded by Noren et al. (1982). Higher lindane value were recorded by Abou-Zeid (1994).; Neamat-Allah (1998), Dabiza et al. (1999).; and Ayoub (2000). While, Pandit et al. (2002) reported lower concentration of lindane in examined butter samples.

Statistical analysis of different organochlorine pesticide residues in butter samples (Table 9 ) revealed that $10(55.6 \%)$ out of 18 examined butter samples having lindane above the maximum residue limit $(10 \mu \mathrm{g} / \mathrm{kg}$ on fat basis) as established by Codex Alimentarious Commission (2004). On the other aspect, the lindane were not detected in $44.4 \%$ of the examined butter samples. While butter samples having total $\mathrm{HCH}$ above the recommended tolerance level $(0.1 \mathrm{mg} / \mathrm{kg})$ of $\mathrm{FAO} / \mathrm{WHO}$ were reported by Neamat-Allah (1998).

Concerning the residues of heptachlor epoxide in butter samples, it is noticed that the residues were detected only in butter samples collected from Abo-Hammad and Al-Husenia with values of 17.05-16.90 and 13.60-13.37 $\mathrm{ppb}$ on fat basis, respectively. In other investigated districts the heptachlor epoxide could not be detected in butter samples.

It is found that the residues of heptachlor epoxide in all examined butter samples lie between 17.05 and 13.37 with an average of $3.384 \pm 1.583$ ppb on fat basis. Abou-Zeid (1994).; and Waliszewski et al. (1997) detected 
Ayoub, M. M. et al.

heptachlor epoxide in butter samples with higher values rather than that in our investigation.

Table (9): Frequency distribution of organochlorine pesticide residues in a total of 18 examined butter samples collected from various districts at Sharkia Governorate

\begin{tabular}{|l|c|c|c|c|c|c|c|}
\hline Organochlorine & \multirow{2}{*}{$\begin{array}{c}\text { M.R.L. } \\
\text { Pesticide residues }\end{array}$} & \multicolumn{2}{|c|}{ Not detected } & \multicolumn{2}{c|}{ Within P.L. } & \multicolumn{2}{c|}{ Over P.L. ${ }^{* *}$} \\
\cline { 3 - 8 } & No. & No & $\%$ & No. & $\%$ & No. & $\%$ \\
\hline Lindane & 10 & 8 & 44.4 & - & - & 10 & 55.6 \\
\hline Heptachlor epoxide & 6 & 14 & 77.8 & - & - & 4 & 22.2 \\
\hline p,p'-DDE & 20 & - & - & - & - & 18 & 100 \\
\hline
\end{tabular}

*M.R.L.: Maximum Residue Limit according to Codex Alimentarius Commission (2004) **P.L.: Permissible Limit

Table (9) indicated that $4(22.2 \%)$ out of 18 examined butter samples having heptachlor epoxide above the maximum residue limit $(6 \mathrm{ppb}$ on fat basis) as recommended by Codex Alimentarious Commission (2004). On the other hand, $14(77.8 \%)$ of examined butter samples having no residues of heptachlor epoxide.

Regarding the residues of $p, p^{\prime}-D D E$ in butter samples, it is clear that all examined samples collected from different districts contained $p, p^{\prime}-D D E$ residues.

Estimation of $p, p^{\prime}-D D E$ in butter samples from different districts, revealed that the values were ranged from $30.0 \mathrm{ppb}$ on fat basis (Al-Husenia district) to $102.50 \mathrm{ppb}$ on fat basis (Kafr-Sakr district), with a mean of $67.063 \pm 4.933 \mathrm{ppb}$ on fat basis. Nearly similar p,p'-DDE levels in butter samples were recorded by Takroo et al. (1985), Abou-Zeid (1994) and Ayoub (2000). On the other hand, higher p,p'-DDE levels were reported by AbuZahw et al. (1993), Neamat-Allah (1998) and Dabiza et al. (1999). Lower p,p'DDE values were obtained by Noren et al. (1982).; Waliszewski et al. (1997).; and Pandit et al. (2002) .

It is shown from Table (9) that all examined butter samples (100\%) having p,p'-DDE above the maximum residue limit (20 ppb on fat basis) as recommended by Codex Alimentarious Commission (2004). These results substantiate what has been reported by Abu-Zahw et al. (1993) who recorded that $p, p^{\prime}-\mathrm{DDE}$ in all local butter samples were exceeded maximum residue limit (0.05 ppm) that established by Codex Alimentarious Commission (1992).

From a forementioned results, it noticed that butter samples having lindane, heptachlor epoxide and p,p'-DDE above the permissible limits.

From public health point of view, the chronic toxicity and sub lethal exposure of lindane and other $\mathrm{HCH}$ isomers produce liver tumors (IARC, 1974). Some authors (Unger and Olsen, 1980; Lopez et al., 1996.; and Jaga and Duvvi, 2001) evaluated the possibility of cancer occurring in humans from DDT exposure. On the other hand, Hayes (1994) recorded that heptachlor are significantly more toxic than DDT.

So, animal studies recorded by Jaga and Brosius (1999) showed a significant association between DDT administration and lymphoma, respiratory cancer, liver cancer and estrogenic effects on mammary tissue. 
Therefore, with the persistence of DDT and DDE in the environment, the potential risk to the health of man, animals and the environment remains.

\section{5-Effect of heat treatment on organochlorine pesticide residues}

A-Effect of common heat treatment on organochlorine pesticide residues in raw buffalo's milk:

This experiment was conducted to determine the effect of common heat treatment (pasteurization, boiling and sterilization) on organochlorine pesticide residues in raw buffalo's milk.

Table (10) revealed that the p,p'-DDE was the only detected organochlorine pesticide residues in tested milk with a mean concentration of $3.21 \mathrm{ppb}$ on milk basis. The milk was treated by pasteurization, boiling and sterilization, and the mean concentration of $p, p^{\prime}$-DDE residues became2.509, 0.932 and $0.2599 \mathrm{ppb}$ on milk basis, respectively with degradation percent of $22.13,71.16 \%$ and 92.8 , respectively.

Table (10): Effect of common heat treatment on organochlorine pesticide residues content of raw buffalo's milk

\begin{tabular}{|c|c|c|c|c|c|c|c|}
\hline \multirow[b]{3}{*}{$\begin{array}{l}\text { Sample } \\
\text { number }\end{array}$} & \multicolumn{7}{|c|}{ p,p'-DDE } \\
\hline & \multirow[b]{2}{*}{ 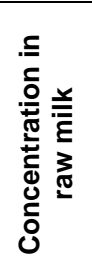 } & \multicolumn{2}{|c|}{ Pasteurization } & \multicolumn{2}{|c|}{ Boiling } & \multicolumn{2}{|c|}{ Sterilization } \\
\hline & & 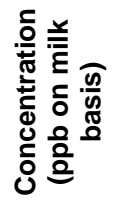 & 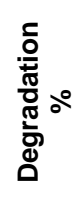 & 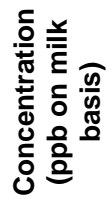 & 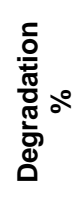 & 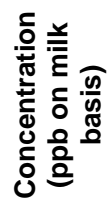 & 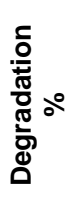 \\
\hline 1 & 2.980 & 2.332 & 21.75 & 0.864 & 71 & 0.238 & 92 \\
\hline 2 & 3.88 & 3.109 & 19.88 & 1.1854 & 69.45 & 0.367 & 90 \\
\hline 3 & 2.771 & 2.085 & 24.75 & 0.747 & 73.03 & 0.175 & 93.7 \\
\hline Mean & 3.210 & 2.509 & 22.13 & 0.932 & 71.16 & 0.2599 & 92.8 \\
\hline
\end{tabular}

From the previously mentioned results, it was noticed that the sterilization of milk had an extensive effect on degradation of p,p'-DDE in raw buffalo's milk followed by boiling and pasteurization. These results are agreement with those findings obtained by Hassan (1987).; Abd-Rabo et al. (1989 $)$.; and Abou-Zied (1994) who concluded that sterilization of milk is the most effective method for reduction of p,p'-DDE residues in milk followed by boiling and finally pasteurization. Moreover, El-Hoshy (1997) recorded that the reduction of $p, p^{\prime}-\mathrm{DDE}$ residues in milk as the result of pasteurization was 21.11 , while it was 70.35 due to boiling.

It was concluded that sterilization of raw milk is the most effective method for reduction of pesticide residues and consequently render the milk safe for human consumption.

B- Effect of butter processing by heat treatment (ghee manufacture) on organochlorine pesticide residues.

Table (11) showed the effect of ghee making on organochlorine pesticide residues content of butter. The analysis of butter samples before processing revealed that the detected residues were lindane, heptachlor epoxide and p,p'-DDE with a mean concentration of 14.213, 15.325 and 
$65.72 \mathrm{ppb}$ on fat basis. After heat treatment for making ghee, the mean concentration of lindane, heptachlor epoxide and p,p'-DDE in produced ghee were $2.948,1.935$ and 15.609 with degradation percent of $79.1,87.50$ and 76.73 , respectively.

Table (11): Effect of butter processing by heat treatment (ghee manufacture) on organochlorine pesticide residues

\begin{tabular}{|c|c|c|c|c|c|c|c|c|c|}
\hline \multirow[b]{3}{*}{$\begin{array}{l}\text { Sample } \\
\text { number }\end{array}$} & \multicolumn{9}{|c|}{ Organochlorine pesticide residues } \\
\hline & \multicolumn{3}{|c|}{ Lindane } & \multicolumn{3}{|c|}{ Heptachlor epoxide } & \multicolumn{3}{|c|}{ p,p'-DDE } \\
\hline & \begin{tabular}{|c|} 
Butter \\
(ppb on \\
fatbasis)
\end{tabular} & $\begin{array}{c}\text { Ghee } \\
\text { (ppb on } \\
\text { fat basis) }\end{array}$ & $\begin{array}{c}\text { Degrada } \\
\text { tion } \%\end{array}$ & $\begin{array}{l}\text { Butter } \\
\text { (ppb on } \\
\text { fatbasis) }\end{array}$ & $\begin{array}{c}\text { Ghee } \\
\text { (ppb on } \\
\text { fatbasis) }\end{array}$ & $\begin{array}{c}\text { Degrad } \\
\text { ation } \\
\%\end{array}$ & \begin{tabular}{|c|} 
Butter \\
(ppb on \\
fatbasis)
\end{tabular} & $\begin{array}{c}\text { Ghee(ppb } \\
\text { on fat } \\
\text { basis) }\end{array}$ & $\begin{array}{l}\text { Degrad } \\
\text { ation \% }\end{array}$ \\
\hline 1 & 18.12 & 3.823 & 78.9 & 13.60 & 1.537 & 88.7 & 34.89 & 6.769 & 80.6 \\
\hline 2 & 10.91 & 2.586 & 76.3 & 17.05 & 2.33 & 36.3 & 65.08 & 18.093 & 72.2 \\
\hline 3 & 13.61 & 2.436 & 82.1 & N.D.* & N.D. & N.D. & 97.19 & 21.965 & 77.4 \\
\hline Mean & 14.213 & 2.948 & 79.1 & 15.325 & 1.935 & 87.50 & 65.72 & 15.609 & 76.73 \\
\hline
\end{tabular}

${ }^{\star}$ N.D.: Not detected

From the obtained results, it is found that butter making processes for production of ghee led to eliminate large quantities of organochlorine pesticide residues. Nearly similar results were obtained by Ayoub (2000) who recorded that heat processing of butter led to reduction of lindane and heptachlor and its epoxide with percentage of 75 and 88, respectively. Also, Zidan et al.(1994) reported that, in final product (samna) after boiling off method, the reduction percentage of lindane was 92.8. Moreover, NeamatAllah (1998) recorded that more than $50 \%$ of added lindane to butter could be degraded or removed during processing into samna due to the effect of heat treatment.

Meanwhile, low degradation percentage was obtained by Abu-Zahw et al. (1993), the authors subjected butter samples to heat treatment to produce ghee and found that the loss percent of $p, p^{\prime}-\mathrm{DDE}$ in cow and buffalo ghee were varied from 9.21 to 46.97 . On the other hand, the reduction of organochlorine pesticide residues by butter boiling-off method can be attributed to heat degradation of pesticide residues and also partial transfer of pesticide residues into morta (Zidan et al., 1994 and Neamat-Allah, 1998).

In conclusion the butter processing by heat treatment (boiling-off method) yielded ghee (samna) with marked decrease in organochlorine pesticide residue content. Therefore, the produced ghee contained organochlorine residues within the permissible limit and render ghee (samna) safe for human consumption.

\section{REFERENCES}

Abd El-Kader, M.A.; Abu-Zahw, M.M.; Tork, I.Y. and Ayoub, M. A. (1994): Organochlorine pesticide residues in milk and some milk products. Egypt. J. Appl. Sci. 9 (9): 267-273.

Abd-Rabo, F.H.; Abou-Dawood, A.E.; Ahmed, N.S. and Hassan, F. A.M. (1989): Heat treatments change amounts of pesticide residues in buffalo's milk. Egyptian J. of Dairy Sci. 17 (2): 349-357. 
Abou-Arab, A.A.K. (1999): Effect of processing and storage of dairy products on lindane residues and metabolites. Food Chemistry. 64 (4): 467-473.

Abou-Arab, A.A.K. (1997): Effect of Ras cheese manufacturing on the stability of DDT and its metabolites. Food Chemistry. 59 (1): 115-119.

Abou-Zeid, A.M.A. (1994): Studies on pesticide residues in milk and some dairy products. Ph.D. Thesis, Faculty of Vet. Med. , Cairo University, Egypt.

Abu-Zahw, M.M.; Abd El-Kader, M.A.; Hegazy, M.E.A. and Mansour, M.A (1993): Pesticide residues in butter and ghee. Bull. of Suez Canal University Appl., Sci., 11 (1): 40-48.

Acqua, A.Del; Ribeiro, M.L.; Trevisan, L.M.V. and Cerqueira, M. (1982): Rapid and economic determination of organochlorine pesticides in milk. Ecletica Quimica, 7: 49- 54.

Ahmed, M.T. (1991): High performance liquid chromatography determination of DDT residues in some commercial brands of milk in Ismailia, Egypt. Z. gesamte Hyg. 37. Heft 3.

Ali, A.A.; Metwally, M.M.; Ahmed, N.S. and Anb, A.K. (1993): Pesticide residues in milk and their distribution among dairy products. Egyptian $\mathrm{J}$. of Dairy Science. 21 (2): 291-299.

Aman, I.M. and Bluthgen, A. (1997): Occurrence of residues of organochlorine pesticides and polychlorinated biphenyls in milk and dairy products from Egypt. Milchwissenschaft. 52 (7): 394-399.

Awasthi, M.D. and Ahuja, A.K. (1995): Organochlorine insecticide residues in bovine milk and commercial baby milk powder. J. of Food Science and Technology. 32 (5): 420-422.

Ayoub, M.M.M. (2000): Monitoring of some organochlorine in some fatty foods. Ph. D. thesis, Department of agricultural Sci. Institute of Environmental Studies and Research. Ain-Shams University, Egypt.

Barkatina, E.N.; Pertsovsky, A.L.; Murokh, V.I.; Kolomits, N.D.; Shulyakovskaya, O.V.; Venger, O.N. and Makarevich, V.I. (1999): Organochlorine pesticide residues in basic food products and diets in the republic of Belarus. Bull. Environ. Contam. Toxicology. 63: 235242.

Camoni, I.; Di Muccio, A.; Pontecorvo, D. and Citti, P. (1983): Study of p,p'DDE impurities in commercial formulations based on dicofol (Kelthane). Nuvi Ann. Ig Microbial 33: 241-247.

Codex Alimentarius Commission (1992): Guide to codex Maximum limits for Pesticide Residues. Part (2) FAO, Rome, Italy.

Codex Alimentarius Commission (2004): Codex committee on pesticide residues. Thirty-Sixth Session. New Delhi, India.

Corneliussen, P.E.; McCully, K. A. ; McMahon, B. and Newsome, W.H. (1984): Pesticide and industrial chemical residues. A.O.A.C. official methods of analysis: 533-562.

Costabeber, I.; Trindade, R. and Fries, L.M. (2001): Organochlorine pesticides levels in cow milk. Alimentaria. 38 (319): 127-129.

Dabiza, N.M.A.; El-Senaity, M.H. and El-Dein, M.M.Z. (1999): Pesticide residues in some market dairy products and distribution of malathion in butter, ghee and Domiati cheese during manufacture. Egypt, J. of Dairy Sci. 27 (2): 345-357. 
Dogheim, S.M.; Almaz, M.M.; Kostandi, S.N. and Hegazy, M.E. (1988): Pesticide residues in milk and fish samples collected from Upper Egypt, J. Association Official Analytical chemists. 71 (5): 872-874.

Dogheim, S.M.; Nasr, E.N.; Almaz, M.M. and El-Tohamy, M.M. (1990): Pesticide residues in milk and fish samples collected from two Egyptian Governorates. J. Association of Official Analytical Chemists. 73 (1): 1921.

El-Afi, A.; Rahmani, M. and Abdennebi, E. H. (1997): Contamination of commercial milk by organochlorine pesticides in Libya. Assiut Veterinary Medical J. 36 (72): 306-312.

El-Hoshy, S.M. (1997): Insecticide residues in milk and influence of heat treatment and bacterial fermentation as safeguard against these pollutants. Assiut Vet. Med. J. 73 (37): 141-155.

El-Marsafy, A.M.; Alla, S.A.G.; Zidan, M.A.; Fahmy, S.M. and Dogheim, S.M. (1999): Monitoring of organochlorine pesticide residues in milk products. Egyptian J. of Agricultural Research. 77 (1): 205-216.

Ejobi, F.; Kanja, L.W.; Kyule, M.N.; Muller, P.; Kruger, J.; Nyeko, J.H.P. and Latigo, A.A.R. (1996): Organochlorine pesticide residues in cow's milk in Uganda. Bull. Environ. Contam. Toxicol. 56: 551-557.

Hassan, F.A.M. (1987): Effect of different processing on pesticide residues in milk. M.V.Sc. Thesis, National Research Centre, Dokki, Cairo, Egypt.

Hayes, A.W. (1994): Principles and methods of Toxicology. $3^{\text {rd }}$ Ed. Raven Press, Ltd., New York ().

IARC (1974): Monograph on the evaluation of carcinogenic risk of chemicals to man. 5, some organochlorine pesticides. International Agency for Research on Cancer (IARC), lyon, France.

Jaga, K. and Brosius, D. (1999): Pesticide exposure: human cancers on the horizon. Rev. Environ. Health. Jan.-Mar.; 14 (1): 39-50.

Jaga, K. and Duvvi, H. (2001): Risk reduction for DDT toxicity and carcinogenesis through dietary modification. J. R. Soc. Health Jun.; 121 (2): 107-13.

Juntunen, L.A.; Bidleman, T.F.; Harner, T. and Parkhurst, W.J. (2000): Toxaphene and other organochlorine pesticides in Alabama air. Environmental Sci. and Technology, 34: 5097-5105.

Kandil, M.A.; Hegazi, M.E. and EL-Sayed, M.A. (1987): Monitoring of pesticide in yoghurt. Egypt. J. Appl. Sci. Third Issue December, 41-46.

Lopez, Carrillo, L.; Torres, Arreola, L.; Torres, Sanchez, L.; Espinosa, Torres, F.; Jimenez, C.; Cebrian, M.; Walliszewski, S. and Saldate, O. (1996): Is DDT use a public health problem in Mexico? Environmental Health Perspectives.104 (6): 584-588.

Losada, A.; Fernandez, N.; Diez, M. J.; Teran, M. T.; Garcia, J. J. and Sierra, M. (1996): Organochlorine pesticide residues in bovine milk from Leon (Spain). Sci. of the Total Environ. 181 (2): 133-135.

Mallatou, H.; Pappas, C. P.; Kondyli, E. and Albanis, T. A. (1997): Pesticide residues in milk and cheeses from Greece. Sci. of the Total Environ. 196 (2): 111-117.

Mukherjee, I. and Gopal, M. (1993): Organochlorine pesticide residues in dairy milk in and around Delhi. J. of the Association of Analytical Chemistry International. 72: 283-286. 
Neamat-Allah, A.A. (1998): Pesticides residues in butter from El-Beharah districts in Egypt and their stability during samna (ghee) processing. Annals of Agric. Moshtohor, 36 (3): 1597-1604.

Noren, K.; Linder, C.E. and Vaz, R. (1982): Levels of organochlorine pesticides and PCB's in Swedish butter, 1971-1976.

Oestreicher, M.L.; Shuman, D.H. and Wurster, C.F.(1971): DDE residues medullary bone formation on birds. Nature (London) 229:571.

Pandit, G.G.; Sharma, S.; Srivastava, P. K. and Sahu, S. K. (2002): Persistent organochlorine pesticide residues in milk and dairy products in India. Food Addit. Contam. Feb.; 19 (2): 153-157.

Pardio, V.T.; Waliszewski, K.N.; Landin, L.A. and Bautista, R.G. (2003): Organochlorine pesticide residues in cow's milk from a tropical region of Mexico. Food Addit. Contam. Mar; 20 (3): 259-269.

Pietrino, D. (1991): Pesticide residues and milk processing. Industria del Latte. 27 (2): 3-32.

Puchwein, G.; Eibeihuber, A.; Brodacz, W.; Muller, J.; Golles, J. and Unger, M. (1990): Pesticide residues in raw milk. Results of a study covering all of Austria, 1985-1988. Bodenkultur 41 (2): 153-175.

Ragab, A.A.; Abd El-Latif, M.S.; Ibrahim, A.M.A. and Smith, C.J. (1996): Indirect competitive ELISA for the quantitative and qualitative analysis of aldrin/dieldrin in Egyptian milk samples from different farm animal species. Food and Agricultural Immunology. 8 (4): 273-278.

Riva, C. Dela and Anadon, A. (1991): Organochlorine pesticides in cow's milk from agricultural region in northwestern Spain. Bull. Environ. Contam. Toxicology. 46: 527-533.

Roos, A.H. and Tuinstra, L.G.M. Th. (1991): Chlorinated insecticides. Monograph on residues and contaminants in milk and milk products. Chapter 5, p. 84. International Dairy Federation, Belgium.

Sandhu, T. S. (1992): Pesticides in food. $3^{\text {rd }}$ World Congress. Food Born Infection and Toxications, 16-19 June Berlin.

Suzuki, T.; Ishikawa, K.; Sato, N. and Sakai K.I. (1979): Determination of chlorinated pesticide residues in food. 1- Rapid screening method for chlorinated pesticides in milk. J. Assoc. Off. Anal. Chem. 62: 681-684.

Takroo, R.; Kaphalia, B.S. and Seth, T.D. (1985): Chlorinated pesticide residues in different brands of butter. J. of Food Science and Technology, India. 22 (1): 57-59.

Unger, M. and Olsen, J. (1980): Organochlorine compounds in the adipose tissue of deceased people with and without cancer. Environmental Research 23: 257-263.

Vreman, K.; Tuinstra, L.G.M.T.; Van Den Hoek, J.; Be Visser, H. and Westerhuis, J. H. (1977): Neth. J. Agric. Sci. 25: 303. (Cited after Aman and Bluthgen, 1997)

Waliszewski, S.M.; Pardio, V.T.; Chantiri, J.N.; Rivera, J. and Aguirre, A.A. (1997): Organochlorine pesticide residues in cow's milk and butter in Mexico. Science of the total Environment 208: 127-132.

Waliszewski, S.M.; Villalobos-Pietrini, R.; Gomez-Arroyo, S. and Infanzon, R.M. (2003): Persistent organochlorine pesticide levels in cow's milk samples from tropical regions of Mexico. Food Addit. Contam. Mar.; 20 (3): 270-275. 


\section{Ayoub, M. M. et al.}

Wong Siu-kay and Lee Wai-on (1997): Survey of organochlorine pesticides in milk in Hong Kong (1993-1995). J. of AOAC International 80 (6) 13321335.

Zapata Moran, A.L.; Santamaria Rios, M.M.; Alvarez Iris, M.; Salazar Vanegas, S. and Muller, U. (1996): Organochlorine pesticide residues in cow milk in Nicaragua. Boletin de la Oficina Sanitaria Panamericana. 120 (6): 483-490.

Zhong, W.; Xu, D.; Chai, Z. and Mao, X. (2003): 2001 survey of organochlorine pesticides in retail milk from Beijing, P. R. China. Food Addit. Contam.; 20 (3): 254-258.

Zidan, Z.H.; Fayed, A.E.; Abou-Arab, A.A. and El-Nockrashy, S.A. (1994): Monitoring some contaminants during the manufacture of some conventional dairy products. Egypt. J. of dairy Sci. 22 (1): 19-29.

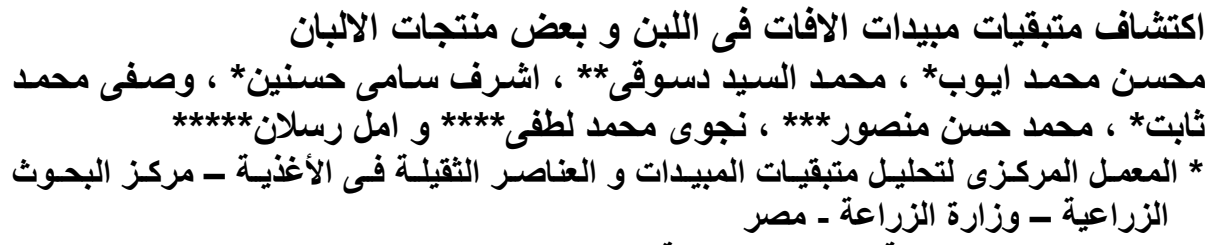

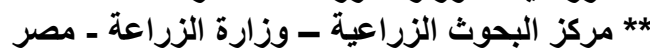

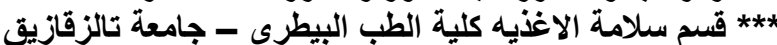

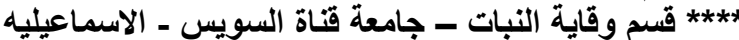

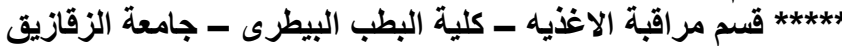

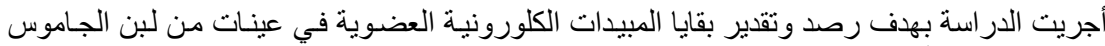

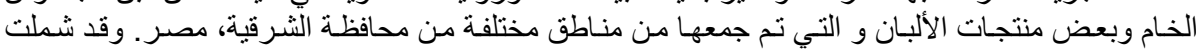

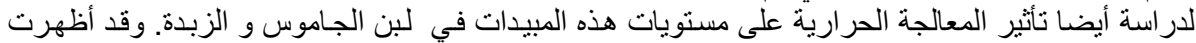

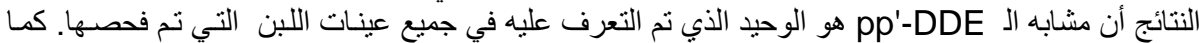

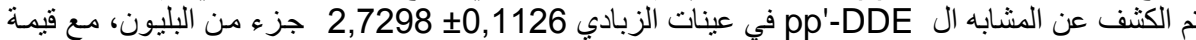

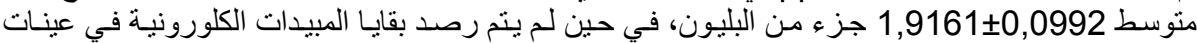

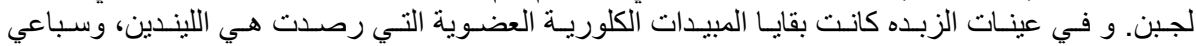

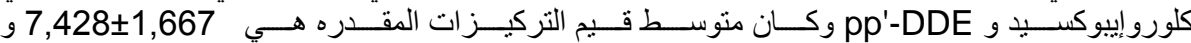

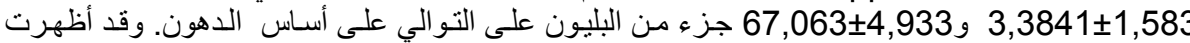

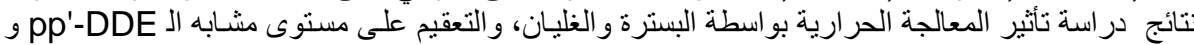

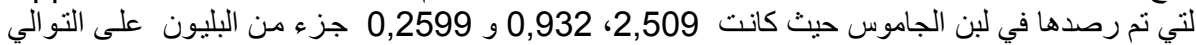

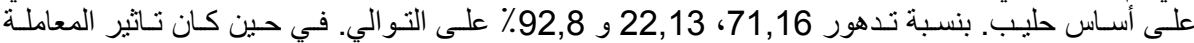

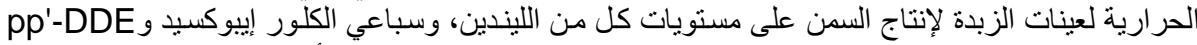

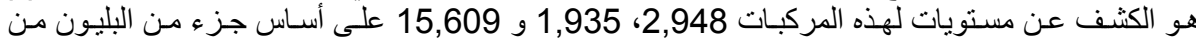

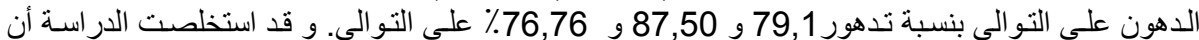

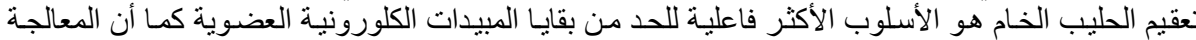
الحر ارية للزبد لانتاج السمنة أدت إلى انخفاض ملحوظ في محتو اها من بقايا المبيدات الكلورونية العضوية العية.

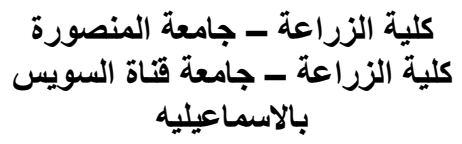

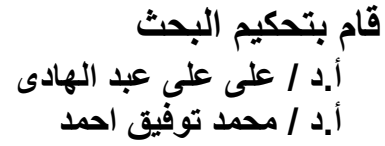

قام بتحكيم البحث

ا.د / محمد توفيق احمد الد الدي. 
J. Plant Prot. and Path., Mansoura Univ., Vol. 3 (8), August, 2012 